\title{
A Study of Effective Learning Strategies In Relation To Intelligence Level across the Science and Arts Academic Streams of Secondary Level
}

\author{
${ }^{1}$ Dr. Sonia Tomar, ${ }^{2}$ Abhilasha Jindal \\ ${ }^{1}$ Assistant professor, $j p$ institute of education, mawana road, meerut. \\ ${ }^{2}$ Research scholar (jrf), department of management, jjt university, jhunjhunu, rajasthan
}

\begin{abstract}
Learning is an important psychological construct in academics. Various learning strategies are used and applied by the students and teachers so as to have effective learning and create effective teaching situations. In this paper research was focused to investigate the effective learning strategies in relation to intelligence level. The present study is done at secondary level and across science and arts stream.

Keywords: Learning, Strategy, Intelligence Level, learning strategies.
\end{abstract}

\section{Introduction}

Learning strategies are organized plans of action or steps for learning. They are done to accomplish a learning outcome, which is what we want to be able to do at the end of our learning experience. Learning strategies are the thoughts and/or actions that students use to complete learning tasks. Learning tasks, however, are the tools that students themselves can employ independently to complete a task. Learning strategies seem to be "tricks" learners how to help them remember things better of to do tasks more efficiently. Teachers are restructuring, retooling and revolutionizing their teaching strategies to adapt to the diversities among the students in the class.

Today's class room teaching situation has shifted from blackboard to keyboard, audio to video, competitiveness to collaboration, instruction to shaping. Every learner has their own way of learning. Some students like to learn in group, some are able to perform well when they learn alone while some learn through sharing. Several researchers have studied what learning strategies are and why they are effective in the learning process. To learn learning strategy better, it will be essential to understand the words' leaning' and 'strategy' separately.

\subsection{Concept of Learning}

H.J. Klausmeier stated learning as a process whereby a change in behavior as a result from some form of experience, activity, training, observation and the like. Sartain et al. defined learning as the process by which a relatively enduring change in behavior occurs as a result of experience and behavior. According to Morgan et al., learning can be defined as any relatively permanent change in behavior that occurs as a result of practice and experience.

\subsection{Concept of Strategy}

The word strategy in its etymological derivation owes its origin from a Greek word 'strategia' and may be defined as plans and specific ways devised and employed for the realization of a goal. Strategy, a word of military origin, refers to a plan of action designed to achieve a particular goal. Strategy is perspective, position, plan and pattern. In short we can say, strategy is a term that refers to a complex web of thoughts, ideas, insights, experiences, goals, expertise, memories, perceptions, and expectations that provides general guidance for specific actions in pursuits of particular ends. B.H. Liddell Hart, in his book 'Strategy' defined as, "the art of the employment of battles as a means to gain the object of war." Concluding his review of wars, policy, strategy and tactics he arrives at this short definition of strategy - "the art of distributing and applying military means to fulfill the ends of policy.' Oxford continues to expand on this definition by stating that learning strategies are specific actions taken by the learner to make learning easier, faster, more enjoyable, more self-directed, more effective, and more transferable to new situations. O'Malley and Chamot, (1990) said that learning strategies are - the special thoughts or behaviors that individuals use to help them comprehend, learn or retain new information. Masters et al. (1993) moved towards a definition of cognitive strategies rather than the term learning strategies. They refer to a definition of cognitive strategies coined by Alley and Deshler (1979, in Masters et al.) as techniques, principles, or rules that will facilitate the acquisition, manipulation, integration, storage, and retrieval of information across situations and settings. They go on to say that cognitive strategies are a fundamental part of the process of acquiring knowledge as well as the tool skills of reading, writing, speaking, listening, note taking, questioning, vocabulary acquisition, time management, reasoning, problem 
solving, and memorization. From reading through the definitions coined by researchers in the area of learning strategies, it would be appropriate to state that learning strategies, in essence, are actions taken by the learner to assist in learning more effectively. Strichart and Mangrum (1993) also state reasons why students need to learn strategic practices for learning. They contend that for learning to occur, students must be able to remember newly acquired information so that they can retrieve the information and use it whenever necessary. Information that is not remembered is of no value to students for dealing with current requirements in or out of school. Since it is virtually impossible for students to remember all the information that is made available to them, it is beneficial to teach students skills which will assist them remember important information. Therefore, it is the contention of Oxford (1990) that teachers will now have to take on a different role, as one of an instructor of learning strategies. She states that "the new teaching capacities also include identifying students' learning strategies, conducting training on learning strategies, and helping learners become more independent." Thus, the teaching learning strategies seem to be a challenge for today's teacher.

\subsection{Concept Of Intelligence}

Intelligence is not a thing or object but it is a way of actions in a situation. Generally speaking, alertness with regard to the actual situation of life is an index of intelligence. Cognitive faculties like observation, memory, imagination, perception and reasoning are also included in the meaning of intelligence. It also includes the capacity for solving practical problems of life. It consists of an individual's those mental or cognitive abilities which help him in solving his actual life problems and leading a happy and well contented life. Different psychologist has given different definition to classify the concept of intelligence. We can divide these definitions into three groups.

- Ability to adjust: It means that intelligence is not adjustment but it is ability or capacity to adjust. This definition has been recognized by following psychologists: Burt - "It is the capacity of flexible adjusts." View of Ross - "Conscious adaptation to new situation is intelligence."

- Ability to learn: It means that intelligence is not to learn but capacity or ability to learn. In this regards views of various supporters are as follows, Thorndike's view, "Intelligence is the ability to make profitable use of past experiences."

- Ability to carry on abstract thinking: It means intelligence is the capacity to carry on abstract thinking. This definition has been recognized by the following psychologists - Burt's view, "Intelligence is the ability to judge well, to comprehend well and to reason well." According to Wechsler, "Intelligence is the aggregate or global capacity of an individual to act purposefully, to think rationally, and to deal effectively with his environment.

\subsection{Learning Strategies}

Learning strategies have been identified by several scholars. Before starting the work on learning strategies, the researcher's have discussed with supervisor, concern teachers and peers a lot. In the present research following seven learning strategies, identified by J.E. Ormrod (2000) that lead to the process of effective learning, are used by researcher as independent variable for the present work.

- Identifying important information: Focus on specific information, structures, key words, phrases, or ideas, words in italics or boldface.

- Taking Notes: In general, note taking is associated with more successful classroom learning. In fact, when students have no opportunity either to take or review notes, they may recall very little of what they hear in lecture.

- Retrieving relevant prior knowledge: Students should think about and use what they already know to help them do the task. They should try and make associations.

- Organizing: Students should plan the task or content sequence and set goals for themselves. They should organize the material and plan how to accomplish the task.

- Elaborating: In order to perform better students should try and elaborate the course material, draw inferences from it or consider its implications.

- Summarizing: Effective summarizing entails separating important information from unimportant, condensing details into more general ideas and identifying important relationships among those general ideas.

- Monitoring Comprehension: Periodically checking should be done by students to make sure that they understood what they were reading or hearing as well as correction should be made by them when students are unable to comprehend. 


\section{Review Of Literature}

Review of literature helped to investigate the various studied undertaken in relation to the same. McWhaw and Abrami (2001) confirmed that students with high level of interest use more strategies than those with low level of interest in a learning area. This is consistent with the result that students have more power or control over the use of strategies than teachers (Eshel \& Kohavi, 2003).

Age Diseth, Therese Kobbeitvedt (2010) "A mediation analysis of achievement motives, goals, learning strategies and academic achievement." Previous research is in conclusive regarding antecedents and consequences of achievement goals and there is a need for more research in order to examine the joint effects of different types of motives and learning strategies as predictors of academic achievements with meta-cognition. Meta-cognition positively affected the use of the four study strategies. The strategy pathway involved positive effects of mastery and performance-approach goals on the use of meta-cognitive and deep cognitive strategies. Further, performance-approach goals positively affected the use of surface cognitive and resource management strategies. The use of meta-cognitive and resource management strategies had a positive and the use of surface cognitive strategies had a negative effect on exam scores.

O. Patrick Ajaja (2010) "Effects of Cooperative Learning Strategy on Junior Secondary School Students Achievement in Integrated Science." The purpose of this study was to determine how the adoption of cooperative learning as an instructional strategy for teaching 'Integrated Science' influences students' achievement and attitude towards studies. The study also determined how moderating variables like sex and ability affect students' achievement in 'Integrated Science' when cooperative learning is used as an instructional strategy. To guide this study, five hypotheses were stated and tested at 0.05 level of significance. The major findings of the study included - a significant higher achievement test scores of students in cooperative learning group than those in traditional classroom, a significant higher attitude scores of students in cooperative learning group than those in traditional classroom, a significant higher achievement test scores of all students of varying abilities in cooperative learning group than those in traditional classroom, a non-significant difference in achievement test scores between the male and female students in the cooperative learning group and non significant interaction effect between sex and ability, sex and method, ability and method and among method, sex and ability on achievement.

Ahmad, Jamaludin and et al. (2010), "The Relationship between Self Concept and Response Towards Student's Academic Achievement Among Students Leaders in University Putra Malaysia.” This is a quantitative research using corelational method. The purpose of this research is to study the relationship between self concept and ability to handle stress on academic achievement of student leaders in University Putra Malaysia. The sample size consists of 106 respondents who are the Student Supreme Council and Student Representative Committee. Tennessee Self Concept Scale (TSCS) was used to evaluate respondents' self concept and for respondents' responses strategy the 'Response Strategy Questionnaire' were used. The respondents' CGPA is used to evaluate their academic achievements. The findings illustrate that there is no significant relationship between self concept and academic achievement. Correlation between self concept and academic achievement is not significant $(\mathrm{r}=0.06, \mathrm{p}=0.950)$. Meanwhile, there is a significant relationship between respondents' response strategies and academic achievements. This would mean that the respondent's response strategy is influenced by his or her academic achievement. The value of frequency contingency, 0.396 illustrate that the relationship is positive and low. The findings from this research will provide information to those who intend to plan beneficial programs for the university or the community in general.

Simsek (2011), "Learning Strategies of Successful and Unsuccessful University Students." The purpose of this study was to assess the most commonly used learning strategies of undergraduate students and how these strategies were related to their academic performance. Results showed that successful students used more, varied and better learning strategies than unsuccessful students. Female students were more effective in selecting and using appropriate strategies than male students. There were a variety of differences among fields of study - students of fine arts used the strategies least, while students of sports used them the most. The most preferred group of strategies was meta-cognitive strategies, whereas the least preferred group was organization strategies. The same pattern was found for the level of success, gender and field of study. The results overall imply that certain strategies contribute to student performance more than other strategies and majority of university students are aware of this situation.

\subsection{Research Objectives}

1. The study was aimed at the following objectives:

2. To study the effective learning strategies of high and low intelligence level of science students.

3. To study the effective learning strategies of high and low intelligence level of arts stream students.

\subsection{Hypotheses of the study}

The present research was conducted to test the following hypotheses: - 
H01: There is no significant difference in high and low intelligence level of science students in terms of effective learning strategies.

H1.1: There is no significant difference between the high and low intelligence level of science students in terms of 'identifying important information' dimension of effective learning strategies.

H1.2: There is no significant difference between the high and low intelligence level of science students in terms of 'taking notes' dimension of effective learning strategies.

H1.3: There is no significant difference between the high and low intelligence level of science students in terms of 'retrieving relevant prior knowledge' dimension of effective learning strategies

H1.4: There is no significant difference between the high and low intelligence level of science students in terms of 'organizing' dimension of effective learning strategies.

H1.5: There is no significant difference between the high and low intelligence level of science students in terms of 'elaborating' dimension of effective learning strategies.

H1.6: There is no significant difference between the high and low intelligence level of science students in terms of 'summarizing' dimension of effective learning strategies.

H1.7: There is no significant difference between the high and low intelligence level of science students in terms of 'monitoring comprehension' dimension of effective learning strategies.

H02: There are no significant differences in the high and low intelligence level of arts students in terms of effective learning strategies.

$\mathrm{H} 2.1$ : There is no significant difference between the high and low intelligence level of arts students in terms of 'identifying important information' dimension of effective learning strategies.

H2.2: There is no significant difference between the high and low intelligence level of arts students in terms of 'taking notes' dimension of effective learning strategies.

$\mathrm{H} 2.3$ : There is no significant difference between the high and low intelligence level of arts students in terms of 'retrieving relevant prior knowledge' dimension of effective learning strategies.

H2.4: There is no significant difference between the high and low intelligence level of arts students in terms of 'organizing' dimension of effective learning strategies.

$\mathrm{H} 2.5$ : There is no significant difference between the high and low intelligence level of arts students in terms of 'elaborating' dimension of effective learning strategies.

H2.6: There is no significant difference between the high and low intelligence level students of arts stream in terms of 'summarizing' dimension of effective learning strategies.

$\mathrm{H} 2.7$ : There is no significant difference between the high and low intelligence level of arts students in terms of 'monitoring comprehension' dimension of effective learning strategies.

\subsection{Research Methodology}

The descriptive survey method was used in this study.

\section{- Sample And Sampling Technique}

The population for the present study comprises all the XI class students (boys and girls) of science and arts stream of secondary level public schools of Meerut commissionary. In the present study, twelve secondary public schools of Ghaziabad and Meerut district out of five districts of Meerut commissionary were surveyed. These schools were selected using random sampling method. A sample of 400 students (200 boys and 200 girls) of science and arts stream was selected from twelve secondary public schools of the Ghaziabad and Meerut district. The sample comprised 200 male (100 science and 100 arts streams) and 200 female (100 science and 100 arts streams) students of class XI (refer table 1).

Table 1: The T Value of ELS Between High And Low Intelligence Level Of Students Of Science Stream

\begin{tabular}{|c|c|c|c|c|c|c|}
\hline \multirow[t]{2}{*}{ S.N. } & \multirow[t]{2}{*}{ Name of Schools } & \multicolumn{2}{|c|}{ Science Stream } & \multicolumn{2}{|c|}{$\begin{array}{c}\text { Arts } \\
\text { Stream }\end{array}$} & \multirow[t]{2}{*}{$\begin{array}{c}\text { Total No. of } \\
\text { Students }\end{array}$} \\
\hline & & Boys & Girls & Boys & Girls & \\
\hline 1. & DPS, Meerut & 8 & 8 & 9 & 8 & 33 \\
\hline 2. & Dewan Public School, Meerut & 8 & 8 & 7 & 8 & 31 \\
\hline 3. & Meerut Public School, Meerut & 8 & 8 & 9 & 8 & 33 \\
\hline 4. & GTB Public School, Meerut & 9 & 9 & 9 & 7 & 34 \\
\hline 5. & Saint Jones Public School, Meerut & 8 & 8 & 8 & 9 & 33 \\
\hline 6. & JP Academy, Meerut & 8 & 9 & 8 & 9 & 34 \\
\hline 7. & Translam Academy Meerut & 8 & 9 & 8 & 8 & 33 \\
\hline 8. & DPS Ghaziabad, UP & 8 & 7 & 9 & 8 & 32 \\
\hline 9. & Dehradun Public school Ghaziabad & 8 & 9 & 9 & 9 & 35 \\
\hline 10. & Gazibad Public School Ghaziabad & 9 & 9 & 8 & 9 & 35 \\
\hline 11. & J.K.G. Public School Ghaziabad & 9 & 8 & 7 & 8 & 32 \\
\hline 12. & KDB Public School Ghaziabad & 9 & 8 & 9 & 9 & 35 \\
\hline & Total & 100 & 100 & 100 & 100 & 400 \\
\hline
\end{tabular}




\section{- Tools Used}

The following tools were applied to study:-

- Effective Learning Strategy Scale (ELSS) was constructed and standardized by the researcher herself.

In the present study the Effective Learning Strategy scale (ELSS) was constructed and standardized by the researcher's themselves because no appropriate tool was available to collect the information regarding the learning strategies adopted by the students across the science and arts streams at secondary school level.

- Group Test of Intelligence (Samoohik Mansik Yogyata Pariksha(I/61)) constructed by Dr. R.K Tandon, 1973(Dept of Psychology, K.G.K College, Moradabad, UP)

\section{- Statistical Techniques Used}

In the present study parametric statistical techniques were used for analysis of data. The Mean, S.D., Ttest were applied to analyze the data.

Table 2: The T Value Of ELS Between High And Low Intelligence Level Of Students Of Science Stream

\begin{tabular}{|c|c|c|c|c|c|c|c|}
\hline $\begin{array}{l}\text { S. } \\
\text { N. }\end{array}$ & & $\begin{array}{l}\text { Students of science } \\
\text { stream }\end{array}$ & $\mathbf{N}$ & $\begin{array}{l}\text { Mean on } \\
\text { ELS }\end{array}$ & $\begin{array}{c}\text { S.D. } \\
\text { on } \\
\text { ELS }\end{array}$ & $\begin{array}{c}\text { t- } \\
\text { value }\end{array}$ & $\begin{array}{c}\text { Significan } \\
\text { ce level }\end{array}$ \\
\hline \multirow[t]{2}{*}{1.} & \multirow[t]{2}{*}{$\begin{array}{l}\text { Identifying important } \\
\text { information }\end{array}$} & High intelligence & 50 & 5.710 & 1.205 & \multirow[t]{2}{*}{7.444} & \multirow[t]{2}{*}{$\begin{array}{l}.01=2.617 \\
.05=1.980\end{array}$} \\
\hline & & Low intelligence & 50 & 4.245 & 1.556 & & \\
\hline \multirow[t]{2}{*}{2.} & \multirow[t]{2}{*}{ Taking Notes } & High intelligence & 50 & 5.915 & 1.801 & \multirow{2}{*}{2.7944} & \multirow{2}{*}{$\begin{array}{l}.01=2.617 \\
.05=1.980\end{array}$} \\
\hline & & Low intelligence & 50 & 5.251 & 1.550 & & \\
\hline \multirow[t]{2}{*}{3.} & \multirow[t]{2}{*}{$\begin{array}{l}\text { Retrieving relevant prior } \\
\text { knowledge }\end{array}$} & High intelligence & 50 & 7.914 & 1.019 & \multirow[t]{2}{*}{12.561} & \multirow[t]{2}{*}{$\begin{array}{l}.01=2.617 \\
.05=1.980\end{array}$} \\
\hline & & Low intelligence & 50 & 6.110 & 1.012 & & \\
\hline \multirow[t]{2}{*}{4.} & \multirow[t]{2}{*}{ Organizing } & High intelligence & 50 & 7.301 & 2.101 & \multirow{2}{*}{8.3731} & \multirow{2}{*}{$\begin{array}{l}.01=2.617 \\
.05=1.980\end{array}$} \\
\hline & & Low intelligence & 50 & 5.011 & 1.751 & & \\
\hline \multirow[t]{2}{*}{5.} & \multirow[t]{2}{*}{ Elaborating } & High intelligence & 50 & 5.915 & 1.801 & \multirow{2}{*}{2.7944} & \multirow{2}{*}{$\begin{array}{l}.01=2.617 \\
.05=1.980\end{array}$} \\
\hline & & Low intelligence & 50 & 5.251 & 1.550 & & \\
\hline \multirow[t]{2}{*}{6.} & \multirow[t]{2}{*}{ Summarizing } & High intelligence & 50 & 6.717 & 2.799 & \multirow{2}{*}{5.934} & \multirow{2}{*}{$\begin{array}{l}.01=2.617 \\
.05=1.980\end{array}$} \\
\hline & & Low intelligence & 50 & 4.713 & 1.890 & & \\
\hline \multirow[t]{2}{*}{7.} & \multirow{2}{*}{$\begin{array}{c}\text { Monitoring } \\
\text { Comprehension }\end{array}$} & High intelligence & 50 & 6.050 & 1.756 & \multirow{2}{*}{2.6383} & \multirow{2}{*}{$\begin{array}{l}.01=2.617 \\
.05=1.980\end{array}$} \\
\hline & & Low intelligence & 50 & 5.505 & 1.088 & & \\
\hline
\end{tabular}

Table 3: Showing The T Value Of ELS Between High And Low Intelligence Level Of Students Of Arts

\begin{tabular}{|c|c|c|c|c|c|c|c|}
\hline \multicolumn{8}{|c|}{ Stream } \\
\hline $\begin{array}{l}\text { S. } \\
\text { N. }\end{array}$ & & $\begin{array}{c}\text { Students of science } \\
\text { stream }\end{array}$ & $\mathbf{N}$ & $\begin{array}{l}\text { Mean on } \\
\text { ELS }\end{array}$ & $\begin{array}{c}\text { S.D. } \\
\text { on } \\
\text { ELS }\end{array}$ & t-value & $\begin{array}{c}\text { Significance } \\
\text { level }\end{array}$ \\
\hline \multirow[t]{2}{*}{1.} & \multirow[t]{2}{*}{$\begin{array}{c}\text { Identifying important } \\
\text { information }\end{array}$} & High intelligence & 50 & 6.831 & 1.801 & \multirow{2}{*}{8.832} & \multirow[t]{2}{*}{$\begin{array}{l}.01=2.617 \\
.05=1.980\end{array}$} \\
\hline & & Low intelligence & 50 & 4.712 & 1.585 & & \\
\hline \multirow[t]{2}{*}{2.} & \multirow[t]{2}{*}{ Taking Notes } & High intelligence & 50 & 5.793 & 1.310 & \multirow{2}{*}{1.7476} & \multirow{2}{*}{$\begin{array}{l}.01=2.617 \\
.05=1.980\end{array}$} \\
\hline & & Low intelligence & 50 & 5.410 & 1.757 & & \\
\hline \multirow[t]{2}{*}{3.} & \multirow{2}{*}{$\begin{array}{l}\text { Retrieving relevant } \\
\text { prior knowledge }\end{array}$} & High intelligence & 50 & 6.912 & 1.001 & \multirow{2}{*}{8.3259} & \multirow{2}{*}{$\begin{array}{l}.01=2.617 \\
.05=1.980\end{array}$} \\
\hline & & Low intelligence & 50 & 6.303 & 1.653 & & \\
\hline \multirow[t]{2}{*}{4.} & \multirow[t]{2}{*}{ Organizing } & High intelligence & 50 & 6.839 & 2.651 & \multirow{2}{*}{2.8441} & \multirow{2}{*}{$\begin{array}{l}.01=2.617 \\
.05=1.980\end{array}$} \\
\hline & & Low intelligence & 50 & 5.985 & 1.410 & & \\
\hline \multirow[t]{2}{*}{5.} & \multirow[t]{2}{*}{ Elaborating } & High intelligence & 50 & 6.575 & 1.504 & \multirow{2}{*}{8.260} & \multirow{2}{*}{$\begin{array}{l}.01=2.617 \\
.05=1.980\end{array}$} \\
\hline & & Low intelligence & 50 & 5.433 & 1.011 & & \\
\hline \multirow[t]{2}{*}{6.} & \multirow[t]{2}{*}{ Summarizing } & High intelligence & 50 & 6.796 & 2.012 & \multirow{2}{*}{1.8129} & \multirow{2}{*}{$\begin{array}{l}.01=2.617 \\
.05=1.980\end{array}$} \\
\hline & & Low intelligence & 50 & 6.207 & 2.551 & & \\
\hline
\end{tabular}


A Study of Effective Learning Strategies in Relation to Intelligence Level across the Science

\begin{tabular}{|c|c|c|c|c|c|c|c|}
\hline 7. & $\begin{array}{c}\text { Monitoring } \\
\text { Comprehension }\end{array}$ & High intelligence & 50 & 7.075 & 2.890 & \multirow{2}{*}{.7934} & $\begin{array}{l}.01=2.617 \\
.05=1.980\end{array}$ \\
\cline { 3 - 6 } & & Low intelligence & 50 & 6.780 & 2.339 & & \\
\hline
\end{tabular}

Table 4: Summary Of Hypotheses Testing

\begin{tabular}{|l|l|l|}
\hline Hypothesis & Test used & Supported/Rejected \\
\hline H1.1 & Mean, standard deviation and t-test & Rejected \\
\hline H1.2 & Mean, standard deviation and t-test & Rejected \\
\hline H1.3 & Mean, standard deviation and t-test & Rejected \\
\hline H1.4 & Mean, standard deviation and t-test & Rejected \\
\hline H1.5 & Mean, standard deviation and t-test & Rejected \\
\hline H1.6 & Mean, standard deviation and t-test & Rejected \\
\hline H1.7 & Mean, standard deviation and t-test & Rejected \\
\hline H2.1 & Mean, standard deviation and t-test & Rejected \\
\hline H2.2 & Mean, standard deviation and t-test & Supported \\
\hline H2.3 & Mean, standard deviation and t-test & Rejected \\
\hline H2.4 & Mean, standard deviation and t-test & Rejected \\
\hline H2.5 & Mean, standard deviation and t-test & Rejected \\
\hline H2.6 & Mean, standard deviation and t-test & Supported \\
\hline H2.7 & Mean, standard deviation and t-test & Supported \\
\hline
\end{tabular}

\section{Discussion Of The Results}

The research proceeds from observation to the conclusions and suggests the implications of the finding to other settings. The present research was focused to investigate the effective learning strategies in relation to intelligence across the science and arts academic streams at secondary level. The objectives were formulated then analyzed and hypothesis wise results are being discussed below-

1. Science students belonging to high Intelligence level have shown their preferences in favour of all the effective learning strategies. The reason being the highly intelligence student are expected to possess greater insight and interest in their learning as compare to student of low intelligence level. Science students of high Intelligence level have more systematic, more particular and more conscious in their performance. Therefore they prefer to organize the study materials properly that will lead to preference for effective learning strategies as identifying important information, taking notes, retrieving relevant prior knowledge, organizing, elaborating, summarizing and monitoring comprehension. When students engage in study activities that help them organize information, they learn more effectively.

- After calculation of significance difference between two means, the ' $t$ ' value (7.444) was found significant at both levels of significance (.01 and .05 level) (refer table 2). It means that high and low intelligence of science students have significant differences in their preference for 'identifying important information' dimension of effective learning strategy.

- After calculation of significance difference between two means, the ' $t$ ' value 2.7944 was found significant at both levels of significance (.01 and .05 level) (refer table 2). It means that high and low intelligence students of science have significant differences in their preference for 'taking notes' dimension of effective learning strategy. The mean differences show that the students of high intelligence prefer the taking notes strategies.

- After calculation of significance difference between two means, the ' $t$ ' value 12.561 was found significant at both levels of significance (.01 and .05 level) (refer table 2). It means that high and low intelligence students of science have significant differences in their preference for 'retrieving relevant prior knowledge' dimension of effective learning strategy.

- After calculation of significance difference between two means, the ' $t$ ' value 8.3731 was found significant at both levels of significance (.01 and .05 level) (refer table 2). It means the high and low intelligence students of science have significant differences in their preference for 'organizing' dimension of effective learning strategy.

- After calculation of significance difference between two means, the ' $t$ ' value 2.7944 was found significant at both levels of significance (.01 and .05 level) (refer table 2). It means the high and low intelligence students of science have significant differences in their preference for 'elaborating' dimension of effective learning strategy.

- After calculation of significance difference between two means, the ' $t$ ' value 5.934 was found significant at both levels of significance (.01 and .05 level) (refer table 2). It means the high and low intelligence students of science have significant differences in their preference for 'summarizing' dimension of effective learning strategy. 
- After calculation of significance difference between two means, the ' $t$ ' value 2.6383 was found significant at both levels of significance (.01 and .05 level) (refer table 2). It means that high and low intelligence students of science have significant differences in their preference for 'monitoring comprehension' dimension of effective learning strategy.

2. Arts students belonging high intelligence level have shown their more preferences for Identifying Important Information, Retrieving Relevant Prior Knowledge, Organizing and Elaborating, and less preferences for Taking Notes, Summarizing and monitoring comprehension. The finding is the natural out com of students understanding,, insight and will to perform better in their studies. They have more capacities to elaborate the studied concepts they are more apt in recalling important the definitions and learned material.

- After calculation of significance difference between two means, the ' $t$ ' value 8.832 was found significant at both levels of significance (.01 and .05 level) (refer table 3). It means that high and low intelligence students of arts stream have significant differences in their preference for 'identifying important information' dimension of effective learning strategy.

- After calculation of significance difference between two means, the ' $t$ ' value 1.7476 was found not significant at both levels of significance (.01 and .05 level) (refer table 3). It means that high and low intelligence students of arts stream have no significant differences in their preference for 'taking notes' dimension of effective learning strategy.

- After calculation of significance difference between two means, the ' $t$ ' value 8.3259 was found significant at both levels of significance (.01 and .05 level) (refer table 3). It means the high and low intelligence students of arts stream have significant differences in their preference for 'retrieving relevant prior knowledge' dimension of effective learning strategy.

- After calculation of significance difference between two means, the ' $t$ ' value 2.8441 was found significant at both levels of significance (.01 and .05 level) (refer table 3). It means that high and low intelligence students of arts stream have significant differences in their preference for 'organizing' dimension of effective learning strategy.

- After calculation of significance difference between two means, the ' $t$ ' value 8.260 was found significant at both levels of significance (.01 and .05 level) (refer table 3). It means that high and low intelligence students of arts stream have significant differences in their preference for 'elaborating' dimension of effective learning strategy.

- After calculation of significance difference between two means, the ' $t$ ' value 1.8129 was not found significant at both levels of significance (.01 and .05 level) (refer table 3). It means the high and low intelligence students of arts stream have no significant differences in their preference for 'Summarizing' dimension of effective learning strategy.

- After calculation of significance difference between two means, the 't' value .7934 was not found significant at both levels of significance (.01 and .05 level) (refer table 3). It means that high and low intelligence students of arts stream have no significant differences in their preference for 'monitoring comprehension' dimension of effective learning strategy.

\section{Conclusions Of The Study}

Conclusions regarding effective learning strategies and intelligence level of science students

- High and low intelligence level students of science stream have significant differences in their preference for 'Identifying important notes' dimension of effective learning strategy. The mean difference shows that the students of high intelligence prefer the 'identifying important notes' strategies.

- High and low intelligence students of science have significant differences in their preference for 'taking notes' dimension of effective learning strategy. The mean differences show that the students of high intelligence prefer the taking notes strategies.

- High and low intelligence students of science have significant differences in their preference for 'retrieving relevant prior knowledge' dimension of effective learning strategy. The mean differences show that the students of high intelligence prefer the retrieving relevant prior knowledge strategies.

- High and low intelligence students of science have significant differences in their preference for 'organizing' dimension of effective learning strategy. The mean differences show that the students of high intelligence prefer the 'organizing' strategies.

- High and low intelligence students of science have significant differences in their preference for 'elaborating' dimension of effective learning strategy.

- High and low intelligence students of science have significant differences in their preference for 'summarizing' dimension of effective learning strategy. 
- High and low intelligence students of science have significant differences in their preference for 'monitoring comprehension' dimension of effective learning strategy.

Conclusions regarding effective learning strategies and intelligence level of arts students

- High and low intelligence students of arts stream have significant differences in their preference for 'identifying important notes' dimension of effective learning strategy.

- High and low intelligence students of arts stream have no significant differences in their preference for 'taking notes' dimension of effective learning strategy.

- High and low intelligence students of arts stream have significant differences in their preference for 'retrieving relevant prior knowledge' dimension of effective learning strategy.

- High and low intelligence students of arts stream have significant differences in their preference for 'organizing' dimension of effective learning strategy.

- High and low intelligence students of arts stream have significant differences in their preference for 'elaborating' dimension of effective learning strategy.

- High and low intelligence students of arts stream have no significant differences in their preference for 'summarizing' dimension of effective learning strategy.

- High and low intelligence students of arts stream have no significant differences in their preference for 'monitoring comprehension' dimension of effective learning strategy.

\section{Limitations Of The Study}

In considering the results emerging from the analyses of our data it is important to mention that one is dealing with the inference from the empirical data and therefore, the generalization appropriate only when made to population which it seems reasonably similar to one employed in the study. All the inferences are approximate, as all inferences are based on empirical data which by their very nature are characterized by some degree of unreliability and depend upon probability of estimate, all such findings pertain to human behavior. Greater confidence can be placed in the conclusion when they are applied to groups of for science and arts stream

\section{Suggestions For Further Research}

From the present study conclusion can be drawn only for seven learning strategies in terms of intelligence. As very few such studies are conducted in India so there is a vast scope of research in this field. So suggestions for further research are: -

- Effectiveness of different teaching and learning strategies and methods can be studied at different levels such as primary level, higher secondary level etc.

- The effective strategies used in present study can be studied by comparing different types of schools.

- Such studies can also be conducted to study the effectiveness of teaching strategies and gender differences.

- The aspiration level of students and teachers can be studied regarding different learning strategies.

- Study can be conducted on students of different characteristics.

\section{Implication of the Study}

Any research study can never be called research study of the education if, it has not been implemented, that is educational implications. Educational implication means, implications of research findings in improving the educational practice. The study in hand was undertaken with basic objective to study the effective learning strategies in terms of intelligence level across the science and arts stream students of XI class in Meerut commissionary. Following are the implication drawn on the basis of the conclusions-

- Findings of the present study will be beneficial to school principals, policymakers, psychologists, teachers and research scholars of the education discipline.

- Findings of the present study will serve the research scholars of the area as base in advancing research studies related to the effectiveness of different learning strategies for different types of learners.

- This study provides knowledge about the suitability of different effective learning strategies across the science and arts stream students and accordingly help in developing different learning models.

- This study may help the teacher educators in the observation and supervision of the lesson plans during teaching practice.

- This study also provides knowledge about different teaching and learning strategies in science and arts stream.

- The findings of the study also provide the basis for effective teaching and learning by using suitable strategies and teaching methods. 
- This study also directs the teacher, how by using different methods and strategy they can guide the thinking of all the pupils in to approximately the same channels. The problems may be raised and defined, solutions may be proposed, tested and conclusions may be drawn-all as a class.

- This study also aware teacher to select such strategies of learning which include more senses and active involvement of students.

- In any further survey along this line additional precision would be maintained by using different learning strategies and their combinations on different kinds of discipline.

\section{Refrences}

[1]. Age Diseth (2011), Self-efficacy, goal orientations and learning strategies as mediators between preceding and subsequent academic achievement. Learning and Individual Differences.

[2]. Age Diseth Therese Kobbeltevedth (2010), A mediation analysis of achievement motives, goals, learning strategies, and academic achievement. British Journal of Educational Psychology.

[3]. Aggarwal J. C. (2004), "Educational Technology-Management and Evaluation", Vinod Pustak Mandir, Agra -2.

[4]. Aggarwal J.C., (2004), Psychology of Learning and Development, Shipra Publications.

[5]. Asubel David P., (1963) “The Psychology of Meaningful Verbal Learning”, Grune and Stratton, New York.

[6]. Barnett, J.E., Di Vesta, E.J. \& Rogozinski (1981) What is learned in note taking ? Journal of Educational Psychology 73, $181-192$.

[7]. Bernard, H. W., (1965); "Psychology of Learning and Teaching", McGraw Hill Book Co., New York. Pp539.

[8]. Best, J.W. (1963), "Research in Education". Prentice Hall, Inc., Englewood Cliffs.

[9]. Besten, K.B. (1997), "The Effects of Block Scheduling on Learning Environment, Instructional Strategies and Academic Achievement". DAI, Vol. 57 (7)

[10]. Bhatnagar, A.B., Meenaskhi Bhatnagar, Anurag Batnagar (2005), Development of Learner and Teaching Leaning Process, Surya Publication.

[11]. Brown, A.L., Campione, J., \& Day, J. (1981), Learning to learn ; On training students to learn from texts. Educational Rersearer, 10 (2), 14-21.

[12]. Buch M.B. (1987), "Third Survey of Research in Education” (1978-83) NCERT, New Delhi.

[13]. Buch M.B. (1992), "Fourth Survey of Research in Education" (1984-89) NCERT, New Delhi.

[14]. Carter, V., Good and Bour A.S. "Methodology of Educational Research Appletten, Craft Ind.

[15]. Chauhan, S.S., (2004); “Advanced Educational Psychology” Sixth revised edition, Vikas Publishing House, New Delhi. P. 236.

[16]. Dee. Lucas, D., \& Larkin, J.H. (1991). Equations in scientific proofs: Effects on comprehension. American Educational Research Journal 28, 661-682,

[17]. Di Vesta, E.J. \& Gray, S.G. (1972), Listening and note taking, Journal of Educational Psychology, 63, 8-14.

[18]. Discovery Publishing House.

[19]. Dole, J.A., Duffy, G.G., Rochler, L.R., \& Pearson, P.D. (1991), Moving from the old to the new : Research on reading comprehension Instruction. Review of Educational Research, 61, 239-264.

[20]. Eble, R.L. (1977), "Encyclopedia of Education Research". The Mcmillan Co. New York.

[21]. Ferguson, G. A., (1966), "Statistical analysis in Psychology and Education", McGraw Hill Book co., New York., pp. 446.

[22]. Garret, H. E., (1969), "Statistic in Psychology and Education", Vakils, Feffers and Simons pvt. 1td., Bombay, , pp. 491.

[23]. Garrett, H.E. (1983). "Statistics in Psychology and Education”. New York: Longmans Green E'co.

[24]. Gerlac vermon S and Ely Donald. P, (1980; "Teaching and Media- A Systematic Approach", Prentice Hall, Inc, Englewood Cliff, New Jersey; II Edition.

[25]. Good, C.V., (1973); "Dictionary of Education", 48th ed. McGraw - Hill Book Co., New York.

[26]. Govt. of India, Ministry of Education (1953). "Report of the Secondary Education Commission", New Delhi.

[27]. Grondlund, N.E. (1973); "Preparing Criterion, Referenced Tests for Classroom Instruction". Macmillan, New York.

[28]. Hale, G.A. (1983). Student's predictions of porse forgetting and the effects of study strategies Journal of Educational Psychology, $75,708-715$

[29]. Hidi, S., \& Anderson. v. (1986). Producing written summaries: Task demands, cognitive operations and implications for instruction. Review of Educational Research, 86. 473-493.

[30]. Holt-Reynolds, D. (1992) Personal history-based beliefs as relevant prior knowledge in course work. American Educational Research Journal, 29 325-349.

[31]. Hyman John, L., (1968), "Research in Education”, Charles E. Merrill Publishing Co., Columbus, Ohio.

[32]. Jones, J.G., (1962); "Teaching with Video-Tape". The Focal Press, London.

[33]. Kahl, B., \& Woloshyn, V.E. (1994). Using elaborative interrogation to facilitate acquisitioin of factual information in cooperative learning setting : one good strategy desercves another. Applied Psychology, 8 465-478.

[34]. Kapoor R. (1987), "Study of Factors Responsible for High and Low Achievement at the Junior High School." Ph.D. in Education, Awadh University.

[35]. Keith, P.F. and B. Moriarty (1997), "Co-operative and Competitive Learning Environments and their effects on behavior, Selfefficacy, and achievement.” The Alberta Journal of Educational Research, Vol. XLIII (2/3), pp. 158-160.

[36]. Kesheng, Yu. (1997), "The effects of Cognitive Tempo and Training in the Hypermedia Learning Achievement on Navigation, Learning Achievement and Self-Efficacy”. DAI, Vol. 57(11), 1997.

[37]. Kiewra, K.A. (1985), Investigating note taking and review: A depth of processing alternative. Educational Psychology. $20,23-32$.

[38]. Kiewra, K.A. (1989), A review of note-taking. The encoding-storage paradigm and beyond. Educational Psychology Review, 147172 .

[39]. King A., (1992), Comparison of self questioning, summarizing, and note taking review as strategies for learning from lectures American Educational Reaserch Journal, 29, 303-232.

[40]. Koul L., (2000), "Methodology of Educational Research" (Second Revised Edition). Vikas Publishing House, New Delhi.

[41]. Mangal, S.K., Shubhra Mangal, (2005), Development of Learner and Teaching Learning Process, International Publishing house.

[42]. Masoud Gholamali, Lavasani, Mokhtar Weisani, Javad Ejei (2011), The role of achievement goals, academic motivation, and learning strategies in statistics anxiety: Testing a causal model. Procedia-Social and Behavioural Sciences, Vol. 15, pg. 1881-1886.

[43]. Mayer R.E. (1984), Aids to text comprehension Educational Psychologist, 19, 30-42.

[44]. Mc Daniel M.A., \& Elnstein, G.O. (1989), Material appropriate processing: A contextualist approach to reading and studying strategies. Educational Psychology Review 1, 113 - 145.

[45]. Means, Rechard, K., (1968), "Methodology in Education”. Charles R. Merrill Publishing Co, Columbus. 
[46]. Ministry of education (1971), "Education and National Development". Report of the education commission, 1964-68, New Delhi, NCERT.

[47]. Nagaraju, C.S. (2002), "Indian Educational Abstracts”. NCERT Delhi Vol. 2 No. 2, July 02.

[48]. Neisser, U., Boodoo, G, Bouchard, T.J., Boykin, A.W. Brody, N., Ceci, S.J., Halpern, D.E, Loehien, J.C., Perloff, R., Sternbeg, R.J., \& Urbina, S. (1996)., Intelligence : Knowns and Unknowns. American psychology, 51, 77-101.

[49]. Ormrod, J.E, (2000), Educational Psychology Developing Learners, III Edition. Pearson Merrill, New Jersey..

[50]. Penny, H.C. et al. (1993), "The effects of the classroom environment on the social and mastery behavior of preschool children with disabilities." Early childhood research quarterly, vol. 8(4), pp. 479-497.

[51]. Prawat, R.S. (1989), Promoting access to knowledge, strategy, and disposition in students: A research synthesis. Review of Educational Research, 59, 1-41.

[52]. Pressey, Robinson and Horrocks (1987), "Psychology in education". Delhi University Book Stall, p. 427.

[53]. Ramana, K.V. (1997), "The effect of classroom learning environment on the academic achievement of the pupils." Ph.D. in Education Osmania University, cited in Indian Education Abstracts, vol. 1., no. 1, 2001, (NCERT Publication) pp. 16-127.

[54]. Schommer M., (1994), An emerging conceptualization of epistemological beliefs and their role in learning. In R. Garner \& P.A. Alexander (Eds.), Beliefs about the text and Instruction with text Hillsdale, N J: Erlbaum

[55]. Schraw, G., \& Wade. S., (1991 April) Selective learning strategies for relevant and important text information. Paper presented at the annual meeting of the American and Educational Research association, Chicago.

[56]. Sharma, A.K. "Educational administration: Some limitations". Trends in education, vol. XXVII, V, I, 1994, pp. 65-68.

[57]. Sharma, kadambri \& Tripta, "Principles and Practice of Language Teaching". Commonwealth Publisher New Delhi P-13.

[58]. Sharma, R. A., (2002); “Technological Foundation of Education,” Loyal book depot, Meerut.

[59]. Sharma, R.A. (1993), “Advanced educational research.” Meerut: Loyal Book Depot.

[60]. Sharma, R.A. (1995), "Fundamental of educational psychology". Meerut: R. Lal Book Depot.

[61]. Sharma, R.A. (2005), Measurement, Evaluation and Statistics, Shipra Publication.

[62]. Shrager, L., \& Mayer, R.E. (1989), Note-taking fosters generative learning strategies in novices. Journal of Educational Psychology, 81, 263-264.

[63]. Spires, H.A. (1990, April) Learning from a lecture: Effects of Comprehension, note taking. Paper presented at the annual meeting of the American Educational Research Association, Boston.

[64]. Taylor, B.M. (1982). Text structure and children's comprehension and memory for expository material. Journal of Educational Psychology. 74, 323-340.

[65]. Van Rossum, E.J., \& Schenk, S.M. (1984). The relationship between learning conception, study strategy and learning outcome. British Journal of Educational Psychology, 54, 73-80.

[66]. Vashistha, K.K. (1987), "Bhartiya Siksha Ki Nai Disha”, Loyal Book Depot, Meerut, 1987.

[67]. Woodworth S., Robert \& Herald Schlosberg, (1971); "Experimental Psychology”. Ox-ford, IBH Publishing Pvt .Ltd, New Delhi P724.

[68]. Yadav K P. (2004); “Encyclopedia of Modern Techniques of Teaching” V-3, Sarup \& Sons, Daryaganj, New Delhi. 